\title{
Zorba el griego ${ }^{\mathrm{A}}$
}

\section{Germán Colmenares}

Zorba. La elasticidad sorprendente de un hombre que es casi un anciano y evidentemente un niño. La pirueta detenida en el espacio que simula un grito y que nos mantiene suspensos de su violencia, de su explosión súbita. La gesticulación expresiva que se queda a medio camino entre la exuberancia incontrolada y un asomo de conciencia que quisiera dar una forma definida y perfecta a la plenitud interior: la mezcla indefinible de una sabiduría del cuerpo, lograda a fuerza de sensaciones, y la torpeza inconsciente de una sabiduría rebosante. Toda coerción o toda norma significa apenas una convención extraña que el cuerpo desaloja a fuerza de sudar, de entregarse a un torbellino irreflexivo que encuentra su propio camino cuando otros cuerpos responden a sus propias incitaciones. Hay una fuerza elemental en ese cuerpo entregado libremente al paisaje o en los gestos que dialogan para decirse cosas simples: tan sencillas que quedan todas contenidas en el gesto, y la palabra resulta una prolongación inútil. El movimiento carece de la malicia de Scapin ${ }^{\mathrm{B}}$ porque es perfectamente espontáneo y se desenvuelve entregado a sí mismo; de ninguna manera está destinado a mostrarse en espectáculo o a avergonzar la pesantez del hombre cargado de pensamientos. Este no hace sino detener la vida en sí mismo y su acción morosa y meditada no cambia un ápice el curso de otras vidas, cargadas de su propia pasión.

Alexis Zorba es un maestro a pesar de sí mismo pues no enseña nada que no pueda indicar con un gesto o con un movimiento. Sólo cuando el discípulo sea capaz de sentir aprenderá la elocuencia de su maestro: el baile frenético, el ritmo que se

A Texto desconocido de Germán Colmenares. Estaba entre los papeles que hemos revisado para la formación de este dossier. El texto está escrito en máquina, papel carta, página y media a un solo espacio, y lleva al final el nombre de Germán Colmenares como autor. Arriba en el encabezamiento se lee: "Zorba el griego", y un renglón abajo, "de Miguel Cacoyannis". Como sabemos, el cine estaba entre las grandes pasiones de Colmenares y en cierta medida de toda su generación. No sabemos si Colmenares se refiere a la película, aunque nos inclinamos a pensarlo, o a la obra de teatro que, posteriormente a la aparición de la película, llevó Cocoyannis a Broadway, y que fue también un éxito. La película, en su momento de exhibición en Colombia, fue objeto de comentarios elogiosos por los críticos que en esos años se interesaban por un cine diferente del habitual, una corriente crítica que venía en ascenso desde finales de los años 1950, en varias ciudades del país. Copiamos, de una enciclopedia general, unas frases sobre el director: "Michael Cacoyannis fue un prominente director teatral y cineasta greco-chipriota, más conocido por su película Zorba el griego, que llevó a Broadway en 1983 en forma de musical. Buena parte de su trabajo tiene origen en los textos clásicos, especialmente en Eurípides, el autor de importantes tragedias griegas". Colmenares publicó varias crónicas de cine en El Espectador

—-Temas propios", por Germán Colmenares, se llamó a veces su columna, que nunca fue regular-, y con anterioridad en la revista Esquemas, había hablado del cine de Ingmar Bergman, de quien comentó dos películas. Puede que buscando con calma se encuentre alguna otra opinión sobre cine en Cromos, en donde por épocas escribió una columna.

B La referencia de G. C. debe ser a "Los enredos de Scapin" (Les Fouberies de Scapin), la comedia de Moliere. 
acompasa con las palpitaciones del cerebro y el corazón. El movimiento del cuerpo se asocia a los misterios de Dyonisos porque suprime el tiempo y acelera la muerte del sufrimiento. La carne renace cuando elimina con el cansancio puramente físico las pulsaciones de la conciencia. El ritmo vital se acelera con la danza y el sentimiento de sí mismo recobra su plenitud. Un sentimiento de sí mismo entero, no fraccionado entre el cerebro y los músculos, sino repartido equitativamente en cada fragmento del ser viviente; la conciencia de sí vibrando en cada músculo y en cada tendón que asimilan el dolor y la alegría y no los dejan concentrarse en esa máquina malsana por su poder iterativo: el cerebro. La alegría y el dolor son casi un impacto físico porque es el cuerpo el que los recibe como el sol o como el alimento, y el que los elimina como en un proceso biológico que da paso a la renovación, a la vida.

Todo lo que no sea esta consciencia de sí aparecerá como algo extraño, como una amenaza a la espontaneidad de la vida. La muerte, el dolor, la alegría, no exigen preguntas: ¿para qué formularlas si no van a encontrar una respuesta? Basta decir, mirándose en el rostro, Zorba, ven; o, Zorba, no ven. ¿Para qué tener a Zorba siempre consigo si puede diluírselo en el movimiento?

Alexis Zorba es un maestro aun en el momento en que concibe una catástrofe. Él crea, como los niños, un castillo de naipes destinado a derrumbarse, y sólo para parodiar el acto creador del hombre, su voluntad de levantar empresas imposibles. Es un apasionado cuando quiere demostrar que los proyectos de su amigo, razonables y calculados, pueden combinarse con lo inesperado y lo imposible, que es lo único que Zorba puede emprender seriamente. Un buen desastre bien calculado y en el fondo inofensivo justifica el deseo de los hombres de llevar a cabo empresas aparentemente razonables. Lo que hace Zorba debe poseer su misma fuerza demoniaca; una catapulta que imita su frenesí y que sale de sus manos para convertirse en un juguete risueño, que llena de pavor y de regocijo a sus amigos.

Zorba, el griego, se mueve incesantemente en medio de este pueblo rudo y primitivo, imponiendo su humanidad, la inteligencia profunda de su cuerpo, los instintos desatados. El amor abandona sus pretextos usuales para convertirse en la inteligencia del cuerpo. El cuerpo todavía ágil siente piedad por el cuerpo inerte, un depositario apenas de los sueños de cuatro almirantes de barbas perfumadas. Él quisiera resucitar ese cuerpo para que la fiesta se perpetuara y los sentidos no conocieran la melancolía del recuerdo. Presiente la soledad que se esconde detrás del orgullo y su sola presencia parece conjurar todos los fantasmas de la muerte. Recoge la dádiva cotidiana de la vida y no se detiene a soñar sino por un instante muy breve. El instante preciso para eternizar su movimiento en el inmenso barco que recorrerá el ancho mundo. 